\title{
DEVELOPING A VIDEO CLIP FOR MATHEMATICS CLASS AT NIGHT HIGH SCHOOL
}

\author{
Kentaro Hara, Yuki Watanabe and Katsuhiko Shimizu \\ Tokyo University of Science, Graduate School of Science, Department of Mathematics and Science Education, Japan
}

\begin{abstract}
This paper is a report on a teaching practice using video clips for mathematics at a night high school in Japan. Night high school were established for students who work in the daytime, but now many students need special assistance. Especially, as night high schools enroll students who have problems in basic mathematics. Its purpose is to develop a class design model that enables such students to learn and master material effectively and efficiently. For such students, we developed a practical lesson design model to learn while watching videos on WEB before class and during class. The lesson design model developed is based on the ADDIE model. The video clips were made with Microsoft PowerPoint and uploaded to YouTube. Also, I built the environments in google classroom and managed learning. There was a problem that half of the students didn't watch the video before the lesson. However, as a result of the class, the score greatly improved for the students who had low test scores. Teachers were able to support students efficiently. As a result, we got results that even for students who had problems in basic mathematics, there was the possibility that their learning was equal to or higher than that which could be obtained from lecture type lessons.
\end{abstract}

\section{KEYWORDS}

Night High School, Mathematics Education, Video Clip, Educational Systems Design, Web-based Learning Communities

\section{INTRODUCTION}

In the Japanese education system, elementary and junior high schools are compulsory, but high schools are optional for students. As a general rule, there is no repeating of school years in junior high school, even if the students' attainment of learning is bad, they can graduate from junior high school. In Japan, 99\% of students who graduated from junior high school go on to high school (MEXT 2016). In other words, there are high schools that accept students with low skill levels. Night high schools are established for students working in the daytime. Basically, the class starts in the evening. However, recently, night high school enrolled various students who don't work (MEXT 2014). There are Students who need special support classes, have problems in the home environment, have difficulty learning, face challenges in communication, and cannot understand Japanese (despite being at a Japanese school) etc. Especially in mathematical basic ability their students have problems. Regarding Japanese education, for active learning style, we need to convert lessons into "active, interactive and deep learning". Therefore, we developed a content design system whereby students learn while watching videos on the web before class and during class. This leaning style is for students who have problems in basic mathematics at night high school. The preceding studied have been targeted to students with ordinary academic ability and high-level students, and to students with low academic ability.

\section{DEVELOPMENT AND PRACTICE}

This system is designed by the ADDIE model (R. A. Reiser, JV Dempsey 2011). The ADDIE model performs is five stages: Analyze, Design, Develop, Implement, and Evaluate.

First, is the stage of Analysis. We analyzed the learning system for students going to night high school. Thereby, we confirmed that it is important that it is made easier to learn for students who have problems in basic mathematics, that both students and teachers benefit, and that the mastery of learning is achieved. 
Second, is the stage of Design. We designed the learning system. According to the stage of Analysis, we designed a learning style where students watch video clips to use for flipped learning on WEB uploaded by us with mobile terminals. We decided to create a video based on classroom content. Bergmann and A. Sams argue that the Flipped Classroom methods goal is to maximize the face-to-face time with the students by minimizing guidance throughout the class (Jonathan Bergmann, Aaron Sams 2015). Our video refers to the video at Kahn Academy and MOOC and is tailored to the target student's ability.

Third, is the stage of Development. We have developed a video clip to achieve the learning system desired. For these students, we decided to practice the lesson design developed in the trigonometric ratio class. We decided to divide the contents of the trigonometric ratio into 12 units and teach them. So, we made 12 videos. The trigonometric ratio is in the teaching content of "Mathematics I" of the Japanese high school curriculum. "Mathematics I" is the subject all high school students have to take in the Japanese curriculum. Given the students' actual circumstances, it is important to explain the video clip by the usual teachers' voice. Also, the length of the video is about 5 minutes because it is appropriate that the video is less than 5 minutes in the classroom reversed learning method (Akahori 2015). To create a video, we inserted a letter and figure in Microsoft PowerPoint, then entered audio and handwritten letters for explanation with Office Mix, PowerPoint add-in. Then upload the video to YouTube. The structure of the video is as follows: (1) cover: unit name and contents of the learning (about $10 \mathrm{sec}$ ), (2) introduction: the explanation of the knowledge part of the unit (about $1 \mathrm{~min} 30 \mathrm{sec}$ ), (3) example: explanation of the title (about $1 \mathrm{~min} 30 \mathrm{sec}$ ), and (4) exercise: commentary on the same level as the example 2 title degree (about $2 \mathrm{~min}$ ). And, we built those environments in google classroom and managed learning. Students learnt while watching videos on the web using school tablets and their mobiles. When creating a video, we used the usual teacher's voice to make students feel secure and keep the students motivated to learn. Teachers provided support to students who failed to learn.

Fourth, is the stage of Implementation. We conducted a learning system using video clips created at the stage of Development, at night high schools in Japan. Because it is easy for students to study at their own pace, teachers can support students efficiently. For example, many students learned at their own pace, so stopped the video part of the way. Therefore, the learning style of watching videos was more efficient in learning time than regular lessons. In addition, the time required for the confirmation test was shortened, and the accuracy rate also increased. At night high school there are students who often do not attend school and students who seem to have developmental disabilities. Students who do not attend school can understand the lesson on the days they are absent using the videos. So, it was easy to understand the lessons when they their attended school. Some students are suspected of having a developmental disorder that means they cannot copy what is written on the blackboard into their notebooks. It was easy for them to study while watching videos using e-mobile. However, half of the students did not watch the video before the lesson.

Fifth, is the stage of Evaluation. In this style of learning, the low skill level students test scores sharply increased. As a result, it was possible to obtain the same level as the lecture style class, and it became clear that there was a possibility that a great effect could be obtained depending on the student. The important point here is that it was carried out at a night high school. It is night high school students who do not understand basic mathematics, so it is important that we confirmed a big effect for such students. The lesson style proposed is also considered effective from the viewpoint of UDL.

The ADDIE model is not finished by doing these 5 stages, each stage is the corrected, and it is tackled cyclically. From now on, we need to verify the lesson design using video.

\section{CONCLUSION}

We clarified the outcomes and issues from the implementation of the lesson style of watching videos, developed in the ADDIE model. We saw that even students with low academic ability can easily understand learning by watching videos. However, half of the students did not watch the video before the lesson. In order to ensure all students, view the video before the lesson, we need to develop the video in a form the students want to see.

For Japanese educations, mobbing to an active learning style, conversion to "active, interactive and deep learning" style lessons is required. At night high school students are diverse and it is not easy to change to an active learning style. From now on, we need to verify the design of lessons using video. 
International Conferences Internet Technologies \& Society 2019 and Sustainability, Technology and Education 2019

\section{REFERENCES}

Jonathan Bergmann \& Aaron Sams, 2015. Flipped Learning: Gateway to Student Engagement. International Society for Technology in Education, USA.

Kanji Akahori, 2015. How to develop teaching materials and in-class flipped learning for using tablet device. Jam House, Tokyo, Japan. (Written by Japanese)

MEXT Central Education Council, 2014. Summary of Deliberation of Secondary Education Subcommittee High School Education Subcommittee deliberation.

http://www.mext.go.jp/b_menu/shingi/chukyo/chukyo3/047/houkoku/1349737.htm (Written by Japanese).

MEXT Central Education Council, 2016. Improvement of guidelines for teaching and necessary measures for kindergartens, elementary school, junior high school, high school and special support school.

http://www.mext.go.jp/b_menu/shingi/chukyo/chukyo0/toushin/1380731.htm (Written by Japanese).

Robert A. Reiser \& John V. Dempsey, 2011. Trends and Issues in Instructional Design and Technology. Pearson Education, USA. 